\title{
Association between polymorphisms in TP53 and MDM2 genes and susceptibility to prostate cancer
}

\author{
MOHAMMAD HASHEMI $^{1,2}$, SHADI AMININIA ${ }^{2}$, MAHBOUBEH EBRAHIMI $^{2}$, NASSER SIMFOROOSH ${ }^{3}$, \\ ABBAS BASIRI $^{3}$, SEYED AMIR MOHSEN ZIAEE $^{3}$, BEHZAD NAROUIE $^{3}$, MEHDI SOTOUDEH $^{3}$, \\ MOHAMMAD JAVAD MOLLAKOUCHEKIAN ${ }^{3}$, ESMAEIL REZGHI MALEKI ${ }^{3}$, HAMIDEH HANAFI-BOJD ${ }^{3}$, \\ MARYAM REZAEI $^{2}$, GHOLAMREZA BAHARI ${ }^{2}$, MOHSEN TAHERI $^{4}$ and SAEID GHAVAMI ${ }^{5}$ \\ ${ }^{1}$ Cellular and Molecular Research Center; ${ }^{2}$ Department of Clinical Biochemistry, School of Medicine, Zahedan University of \\ Medical Sciences, Zahedan 98167-43181; ${ }^{3}$ Urology and Nephrology Research Center, Department of Urology, \\ Shahid Labbafinejad Medical Center, Shahid Beheshti University of Medical Sciences, Tehran 198396-3113; ${ }^{4}$ Genetics of \\ Non Communicable Disease Research Center, Zahedan University of Medical Sciences, Zahedan 98167-43181, Iran; \\ ${ }^{5}$ Department of Human Anatomy and Cell Science, College of Medicine, \\ Faculty of Health Sciences, University of Manitoba, Winnipeg, MB R3E 0J9, Canada
}

Received February 18, 2016; Accepted October 5, 2016

DOI: $10.3892 / \mathrm{ol} .2017 .5739$

\begin{abstract}
Tumor protein 53 (TP53), a tumor suppressor gene, is a vital cellular cancer suppressor in multicellular organisms. Murine double minute-2 (MDM2) is an oncoprotein that inhibits TP53 activity. A number of studies have examined the association of TP53 and MDM2 polymorphisms with the risk of common forms of cancer, but the findings remain inconclusive. The present study aimed to evaluate the impact of the 40-bp insertion/deletion (I/D) polymorphism (rs3730485) in the $M D M 2$ promoter region and the 16-bp I/D polymorphism (rs17878362) in TP53 on the susceptibility of prostate cancer (PCa) in a sample of the Iranian population. This case-control study included 103 patients with pathologically confirmed $\mathrm{PCa}$ and 142 patients with benign prostatic hyperplasia. The MDM2 40-bp I/D and TP53 16-bp I/D polymorphism was determined using polymerase chain reaction analysis. The results demonstrated that the MDM2 40-bp I/D polymorphism increased the risk of $\mathrm{PCa}$ in a co-dominant inheritance model [odds ratio $(\mathrm{OR})=1.88 ; 95 \%$ confidence interval $(\mathrm{CI})=1.11-3.19 ; \mathrm{P}=0.023$, $\mathrm{D} / \mathrm{D}$ vs. I/I], while this variant marginally increased the risk of $\mathrm{PCa}$ in a dominant model $(\mathrm{OR}=1.69 ; 95 \% \mathrm{CI}=1.00-2.83$; $\mathrm{P}=0.051, \mathrm{I} / \mathrm{D}+\mathrm{D} / \mathrm{D}$ vs. I/I). No significant association was observed between the TP53 16-bp I/D polymorphism and $\mathrm{PCa}$. In conclusion, the present study demonstrated that the
\end{abstract}

Correspondence to: Professor Mohammad Hashemi, Department of Clinical Biochemistry, School of Medicine, Zahedan University of Medical Sciences, Khalij Fars Boulevard, Zahedan 98167-43181, Iran

E-mail: mhd.hashemi@gmail.com

Key words: prostate cancer, tumor protein 53, murine double minute-2, insertion/deletion, polymorphism 40-bp I/D polymorphism in the $M D M 2$ promoter increased the risk of PCa in an Iranian population. Further investigations with diverse ethnicities and larger sample sizes are required to verify these results.

\section{Introduction}

Prostate cancer (PCa) is the most prevalent form of cancer among males in the United States (1). In Iran, the incidence of PCa is $\sim 9.6$ cases per 100,000 individuals, with a range of 3.2-16.0 per 100,000 in various geographical settings $(2,3)$. This is comparable with the Asia-Pacific region (9.9 per 100,000), but significantly lower than in the rest of the world $(32.8$ per 100,000 ) (4). The median age at diagnosis is $\sim 66$ years and the 5-year survival rate of patients with $\mathrm{PCa}$ has been estimated to be $98.9 \%$ (5).

The molecular mechanisms underlying the progression and carcinogenesis of $\mathrm{PCa}$ have not yet been clarified. Additional molecular markers that may be employed to detect $\mathrm{PCa}$ and to individualize patient therapy and prognosis are of great clinical importance. A number of large cohort and case-control studies with various populations suggest that family history is a primary risk factor for $\mathrm{PCa}$ (6-10).

In humans, the tumor protein 53 (TP53) gene is located on the short arm of chromosome 17 (17p13.1) (11). TP53, an important tumor suppressor gene, is a crucial regulator of apoptosis and the cell cycle (12-15). When it is mutated, this regulation may be lost, leading to uncontrolled cell proliferation and potentially tumorigenesis (16).

The human MDM2 gene is mapped on chromosome 12q14.3-15 (17). MDM2 functions as a key negative regulator of TP53 (18), inhibiting the transcriptional activity of TP53 and enhancing proteolytic P53 degradation (19).

The impact of a 16-bp duplication [insertion (I)/deletion (D)] polymorphism (rs17878362) within intron 3 of TP53 and a 40-bp I/D variant of $M D M 2$ on cancer susceptibility has been 
examined, but studies have reported conflicting results (20-28). Therefore, the current study aimed to determine the possible association of the 16-bp I/D polymorphism within intron 3 of TP53 and the 40-bp I/D polymorphism in the promoter region of $M D M 2$ with PCa in a sample of an Iranian population.

\section{Materials and methods}

Patients. The present case-control study enrolled 103 histopathologically-confirmed patients with PCa and 142 age-matched men with benign prostatic hyperplasia (BPH), who had been referred to the Department of Urology, Shahid Labbafinejad Medical Center, Shahid Beheshti University of Medical Sciences (Tehran, Iran). The enrollment process and study design were performed as previously described (29). Ethical approval for the study was obtained from the Ethics Committee of Zahedan University of Medical Sciences, and written informed consent was obtained from all participating patients. Blood samples were collected in EDTA-containing tubes from patients and controls, and DNA was extracted using the salting out method as previously described (30).

Genotyping. MDM2 40-bp I/D polymorphism genotyping was performed using forward (5'-GACCACTATGTTTAAGGA AG-3') and reverse (5'-TGACTCACCTACTTTCCCAC-3') primers, as described previously (28). Polymerase chain reaction (PCR) was performed using commercially available Prime Taq Premix (Genet Bio, Daejeon, South Korea), according to the manufacturer's recommended protocol. The PCR cycling conditions were as follows: An initial denaturation at $95^{\circ} \mathrm{C}$ for $5 \mathrm{~min}$, followed by 30 cycles at $95^{\circ} \mathrm{C}$ for $30 \mathrm{sec}, 59^{\circ} \mathrm{C}$ for $25 \mathrm{sec}, 72^{\circ} \mathrm{C}$ for $30 \mathrm{sec}$ and a final extension step at $72^{\circ} \mathrm{C}$ for $10 \mathrm{~min}$. The product sizes for the I and D alleles were 287 and $247 \mathrm{bp}$, respectively. The PCR products were verified using $2.5 \%$ agarose gels containing $0.5 \mu \mathrm{g} / \mathrm{ml}$ ethidium bromide, and observed under UV light (Fig. 1).

Genotyping of the 16-bp duplication polymorphism in TP53 was performed by PCR using forward (5'-CTGAAAACAACG TTCTGGTA-3') and reverse (5'-AAGGGGGACTGTAGATGG GTG-3') primers (31) as previously described (32). The PCR conditions were as follows: An initial denaturation step at $95^{\circ} \mathrm{C}$ for $5 \mathrm{~min}$, followed by 30 cycles at $95^{\circ} \mathrm{C}$ for $30 \mathrm{sec}, 60^{\circ} \mathrm{C}$ for $30 \mathrm{sec}$ and $72^{\circ} \mathrm{C}$ for $30 \mathrm{sec}$, with a final extension step at $72^{\circ} \mathrm{C}$ for $10 \mathrm{~min}$. The TP53 wild type allele, the D allele (no duplication), resulted in a 119-bp fragment and the variant alleles, the I allele (with 16-bp duplication), resulted in a 135-bp fragment (Fig. 2). Approximately $15 \%$ of the samples were randomly selected for confirmation and the results were all consistent.

Statistical analysis. Statistical analysis was performed using SPSS v18 (SPSS, Inc., Chicago, IL, USA). Continuous and categorical data were analyzed using the independent sample $t$-test and the $\chi^{2}$ test, respectively. Associations of the MDM2 40-bp I/D and the TP53 16-bp I/D polymorphism with PCa were calculated by computing the odds ratio (OR) and $95 \%$ confidence intervals (95\% CIs) from logistic regression analyses. The genotype distribution of variants was tested for Hardy-Weinberg equilibrium (HWE) separately for cases and controls. $\mathrm{P}<0.05$ was considered to indicate a statistically significant difference.
Table I. Clinicopathological characteristics of patients with prostate cancer.

\begin{tabular}{|c|c|}
\hline Characteristics & $\begin{array}{c}\text { Number of } \\
\text { patients }\end{array}$ \\
\hline Mean age, years (range) & $61.0(43-72)$ \\
\hline PSA level at diagnosis $(\mathrm{ng} / \mathrm{ml})$, mean $\pm \mathrm{SD}$ & $14.1 \pm 13.3$ \\
\hline \multicolumn{2}{|l|}{ Gleason Score, n (\%) } \\
\hline$\leq 6$ & $36(35)$ \\
\hline 7 & $46(44.7)$ \\
\hline$>7$ & $21(20.4)$ \\
\hline \multicolumn{2}{|l|}{ Stage, n $(\%)$} \\
\hline pT1 & $8(7.8)$ \\
\hline $\mathrm{pT} 2 \mathrm{a}$ & $20(19.4)$ \\
\hline pT2b & $7(6.8)$ \\
\hline pT2c & $39(37.9)$ \\
\hline pT3a & $8(7.8)$ \\
\hline pT3b & $21(20.4)$ \\
\hline Perineural invasion, $\mathrm{n}(\%)$ & $60(58.3)$ \\
\hline Impotency, n (\%) & $18(17.5)$ \\
\hline Loss of libido, n (\%) & $16(15.5)$ \\
\hline Post-void residual, mean $\pm \mathrm{SD}(\mathrm{ml})$ & $26.7 \pm 27.6$ \\
\hline Addiction, n (\%) & $4(3.9)$ \\
\hline Hypertension, n (\%) & $8(7.8)$ \\
\hline Diabetes mellitus, n (\%) & $7(6.8)$ \\
\hline History of smoking, $\mathrm{n}(\%)$ & $12(11.7)$ \\
\hline Alcohol consumption, n (\%) & $1(0.97)$ \\
\hline
\end{tabular}

PSA, prostate specific antigen; SD, standard deviation. pT1, pT2a, pT2b, pT2c, pT3a and pT3b are clinical stages of prostate cancer.

\section{Results}

Patient characteristics. In total, 103 patients with $\mathrm{PCa}$ were enrolled with a mean age of $61.03 \pm 6.03$ years, and 142 patients with BPH (control group) were enrolled with a mean age of $62.57 \pm 7.85$ years. No significant difference in age was observed between the groups $(\mathrm{P}=0.097)$. The clinicopathological characteristics of the patients with $\mathrm{PCa}$ are summarized in Table I.

TP53 16-bp I/D and MDM2 40-bp I/D polymorphism variant and PCa risk. The TP53 16-bp I/D variant was not associated with $\mathrm{PCa}$ in any tested inheritance models (co-dominant, dominant and recessive; Table II). The genotype and allele frequencies of the MDM2 40-bp I/D polymorphism in patients with $\mathrm{PCa}$ and the controls are presented in Table III. A significant difference was observed between patients with $\mathrm{PCa}$ and controls regarding the MDM2 40-bp I/D polymorphism ( $\left.\chi^{2}=7.06 ; \mathrm{P}=0.029\right)$. The $M D M 240$-bp I/D polymorphism increased the risk of $\mathrm{PCa}$ in a co-dominant inheritance model $(\mathrm{OR}=1.88 ; 95 \% \mathrm{CI}=1.11-3.19 ; \mathrm{P}=0.023$, $\mathrm{I} / \mathrm{D}$ vs. I/I), while the variant marginally increased the risk of $\mathrm{PCa}$ in a dominant model $(\mathrm{OR}=1.69 ; 95 \% \mathrm{CI}=1.00-2.83$; $\mathrm{P}=0.051, \mathrm{I} / \mathrm{D}+\mathrm{D} / \mathrm{D}$ vs. I/I). The $\mathrm{D}$ allele was not associated 


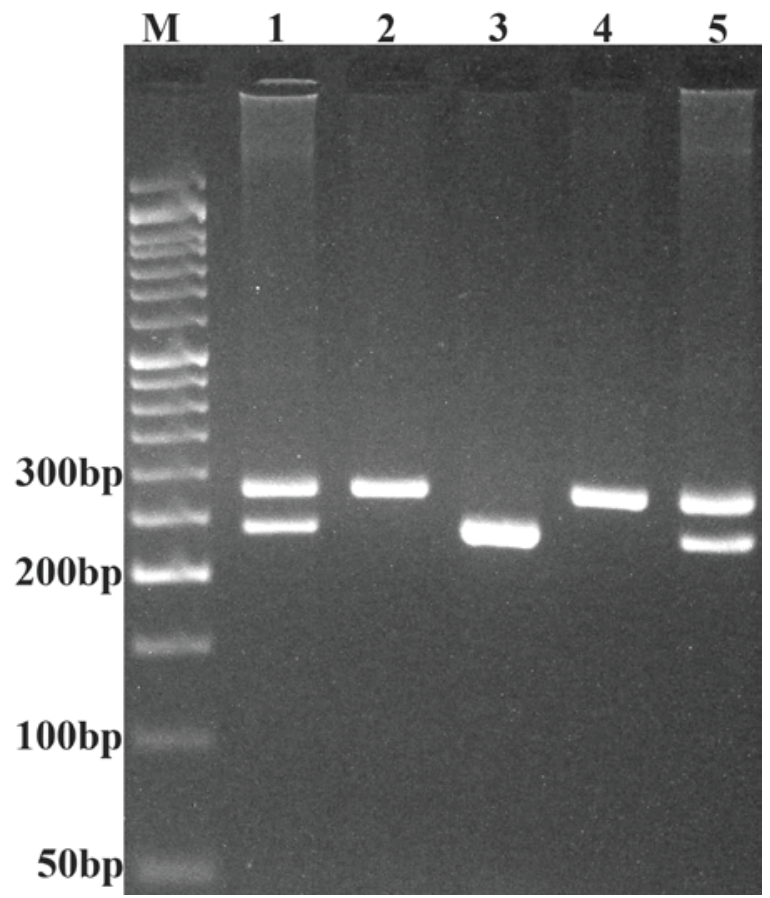

Figure 1. Electrophoresis pattern of the polymerase chain reaction product of the 40-bp I/D polymorphism of murine double minute- 2 resolved by $2.5 \%$ agarose gel electrophoresis. M, 50 bp DNA marker; lanes 1 and 5, I/D; lanes 2 and 4, I/I; lane 3, D/D. I, insertion; D, deletion.

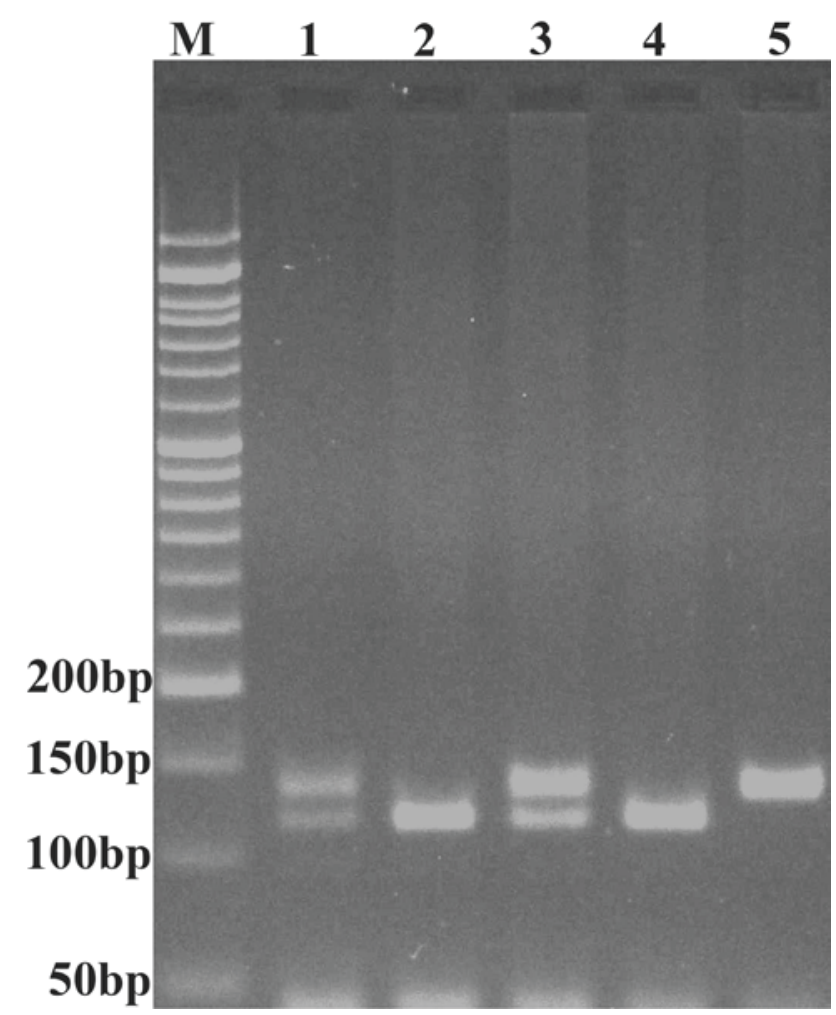

Figure 2. Representative polymerase chain reaction products resolved by agarose gel electrophoresis to detect the presence or absence of the $16 \mathrm{bp} \mathrm{I/D}$ polymorphism of the tumor protein 53 gene. M, 50 bp DNA marker; lanes 1 and 3, I/D; lanes 2 and 4, D/D; lane 5, I/I. I, insertion; D, deletion.

with $\mathrm{PCa}(\mathrm{OR}=1.23 ; 95 \% \mathrm{CI}=0.84-1.82 ; \mathrm{P}=0.320)$, compared with the I allele.
The MDM2 I/D and TP53 16-bp variant genotype frequencies were individually tested for patients and controls using the HWE. The TP53 16-bp I/D polymorphism in patients and controls were observed to be in equilibrium $\left(\chi^{2}=0.002\right.$, $\mathrm{P}=0.958 ; \chi^{2}=0.52, \mathrm{P}=0.473$, respectively). For the $M D M 2$ 40-bp I/D, the genotype was in equilibrium in controls $\left(\chi^{2}=0.51 ; \mathrm{P}=0.820\right)$, but not in patients $\left(\chi^{2}=10.36, \mathrm{P}=0.001\right)$.

Association of MDM2 I/D and TP53 I/D with clinicopathological characteristics. As presented in Table IV, the MDM2 I/D variant was not associated with clinicopathological characteristics, including age, stage, prostate specific antigen level, grade (Gleason score), perineural invasion or surgical margin. However, there was an association between the TP53 I/D polymorphism and surgical margin $(\mathrm{P}=0.035)$.

\section{Discussion}

It has been suggested that genetic and environmental factors each contribute to the pathogenesis of human PCa (33-35). The present study investigated the impact of the 16-bp I/D polymorphism within intron 3 of TP53 and the 40-bp I/D polymorphism in the promoter region of $M D M 2$ on the risk of $\mathrm{PCa}$ in a sample of the Iranian population. The results demonstrated that the TP53 16-bp I/D polymorphism was not associated with the risk of PCa. However, a significant association was observed between the MDM2 I/D variant and the risk of PCa, and the I/D genotype increased the risk of PCa, compared with I/I.

The TP53 gene is a key tumor suppressor that encodes a 53-kDa protein, which is essential in DNA repair, cell cycle arrest and apoptosis in response to DNA damage (12-15,26,36). TP53 mutations are the most frequent gene mutations in the majority of types of human cancer, and they permit cells to proliferate and survive (37). Rapid phosphorylation of TP53 by ataxia telangiectasia mutated (ATM) following DNA damage leads to increased TP53 stability and activity $(38,39)$. TP53-induced gene expression leads to cell cycle arrest and apoptosis (40). When TP53 is mutated, this effect may be lost, resulting in uncontrolled cell proliferation that may result in tumorigenesis (16). It has been proposed that genetic polymorphisms in TP53 may affect a number of its functions (41).

MDM2, a key negative regulator of TP53, is able to bind directly to TP53 and inhibit its transcriptional activity (18). MDM2 also promotes the ubiquitination and subsequent degradation of TP53 $(19,42)$. Promoter polymorphisms in the MDM2 gene may affect MDM2 cellular protein levels (43), and MDM2 overexpression has been reported in several forms of human cancer (44-46).

In agreement with the results of the present study, Mittal et al (47) reported no significant association between the TP53 16-bp I/D polymorphism and PCa in an Indian population. Certain studies have demonstrated that the 16-bp I/D variant increased the risk of various types of cancer, including breast $(20,21,48-50)$, colorectal $(22)$, lung $(23,24,51)$, esophageal and gastric (52) cancer. Conversely, a number of studies observed no association between the TP53 16-bp I/D variant and certain forms of cancer, including breast (53) and pancreatic (54) cancer. The 16-bp I/D polymorphism in TP53 has been demonstrated to be associated with lymph node metastasis in breast cancer (55). 
Table II. Genotypic and allelic frequencies of the TP53 16-bp I/D polymorphism in patients with PCa, and in controls.

\begin{tabular}{|c|c|c|c|c|}
\hline TP53 16-bp I/D & PCa, n (\%) & Control, n (\%) & OR $(95 \% \mathrm{CI})$ & P-value \\
\hline \multicolumn{5}{|l|}{ Codominant } \\
\hline $\mathrm{D} / \mathrm{D}$ & $36(35.0)$ & $57(40.1)$ & 1.00 & - \\
\hline $\mathrm{D} / \mathrm{I}$ & $50(48.5)$ & $69(48.6)$ & $1.15(0.66-1.99)$ & 0.673 \\
\hline $\mathrm{I} / \mathrm{I}$ & $17(16.5)$ & $16(11.3)$ & $1.68(0.76-3.76)$ & 0.223 \\
\hline \multicolumn{5}{|l|}{ Dominant } \\
\hline $\mathrm{D} / \mathrm{D}$ & $36(35.0)$ & $57(40.1)$ & 1.00 & - \\
\hline $\mathrm{D} / \mathrm{I}+\mathrm{I} / \mathrm{I}$ & $67(65.0)$ & $84(59.9)$ & $1.26(0.75-2.14)$ & 0.425 \\
\hline \multicolumn{5}{|l|}{ Recessive } \\
\hline $\mathrm{DD}+\mathrm{D} / \mathrm{I}$ & $86(83.5)$ & $126(88.7)$ & 1.00 & - \\
\hline $\mathrm{I} / \mathrm{I}$ & $17(16.5)$ & $16(11.3)$ & $1.56(0.75-3.25)$ & 0.259 \\
\hline \multicolumn{5}{|l|}{ Allele } \\
\hline $\mathrm{D}$ & $122(59.2)$ & $183(64.4)$ & & - \\
\hline I & $84(40.8)$ & $101(35.6)$ & $1.25(0.86-1.81)$ & 0.258 \\
\hline
\end{tabular}

TP53, tumor protein 53; I, Insertion; D, deletion; PCa, prostate cancer; OR, odds ratio; CI, confidence interval.

Table III. Genotypic and allelic frequencies of the MDM2 40-bp I/D polymorphism in patients with PCa and controls.

\begin{tabular}{|c|c|c|c|c|}
\hline MDM2 40-bp I/D & $\mathrm{PCa}, \mathrm{n}(\%)$ & Control, n (\%) & OR $(95 \% \mathrm{CI})$ & P-value \\
\hline \multicolumn{5}{|l|}{ Codominant } \\
\hline $\mathrm{I} / \mathrm{I}$ & $39(37.9)$ & $72(50.7)$ & 1.00 & - \\
\hline $\mathrm{I} / \mathrm{D}$ & $60(58.2)$ & $59(41.6)$ & $1.88(1.11-3.19)$ & 0.023 \\
\hline $\mathrm{D} / \mathrm{D}$ & $4(3.9)$ & $11(7.7)$ & $0.67(0.20-2.25)$ & 0.578 \\
\hline \multicolumn{5}{|l|}{ Dominant } \\
\hline $\mathrm{I} / \mathrm{I}$ & 39 (37.9) & $72(50.7)$ & 1.00 & - \\
\hline $\mathrm{I} / \mathrm{D}+\mathrm{D} / \mathrm{D}$ & $64(62.1)$ & $70(49.3)$ & $1.69(1.00-2.83)$ & 0.051 \\
\hline \multicolumn{5}{|l|}{ Recessive } \\
\hline $\mathrm{I} / \mathrm{I}+\mathrm{I} / \mathrm{D}$ & $99(96.1)$ & $131(92.3)$ & 1.00 & - \\
\hline $\mathrm{D} / \mathrm{D}$ & $4(3.9)$ & $11(7.7)$ & $0.45(0.15-1.56)$ & 0.284 \\
\hline \multicolumn{5}{|l|}{ Alleles } \\
\hline I & $138(67.0)$ & $203(71.5)$ & 1.00 & - \\
\hline $\mathrm{D}$ & $68(33.0)$ & $81(28.5)$ & $1.23(0.84-1.82)$ & 0.320 \\
\hline
\end{tabular}

MDM2, murine double minute-2; I, insertion; D, deletion; PCa, prostate cancer; OR, odds ratio; CI, confidence interval.

The intron sequences in TP53 are involved in regulating gene expression and in DNA-protein interactions $(56,57)$. It has been proposed that the TP53 intron 3 16-bp I variant is associated with lower levels of TP53 transcripts, which suggests that this duplication polymorphism causes an alteration in mRNA processing and may be a risk factor for developing cancer (57). In addition, it has been suggested that the TP53 codon 72 variant may be a low-penetrant risk factor for developing PCa in Caucasians, but not in Asians (58), and variants within the TP53 binding sites may be valuable biomarkers for the prognosis of patients with $\mathrm{PCa}$ (59).

The current study observed that the 40-bp I/D polymorphism in the $M D M 2$ promoter increased the risk of $\mathrm{PCa}$. A recent study reported that the MDM2 40-bp I/D variant increased the risk of breast cancer in an Iranian population (28). Furthermore, a significant association between $M D M 2$ I/D and lung cancer was detected in the Chinese population (26). In addition, the MDM2 40-bp I/D variant has been demonstrated to be a risk factor for hepatocellular carcinoma in the Chinese population (25). By contrast, no association was identified between the MDM2 40-bp I/D polymorphism and breast cancer in the Chinese population (27).

The limitations of the present study are as follows: Firstly, relatively small sample sizes were used, therefore repetition with larger samples is required; secondly, gene-environment interactions were not determined. It has been proposed that environmental and genetic factors each serve a role in $\mathrm{PCa}$ development. In conclusion, the results of the present study 
Table IV. Association between MDM2 40-bp I/D and TP53 16-bp I/D polymorphisms with clinicopathological parameters in patients with prostate cancer.

\begin{tabular}{|c|c|c|c|c|c|c|c|c|}
\hline \multirow[b]{2}{*}{ Factors } & \multicolumn{3}{|c|}{ MDM2 40-bp I/D } & \multirow[b]{2}{*}{ P-value } & \multicolumn{3}{|c|}{ TP53 16-bp I/D } & \multirow[b]{2}{*}{ P-value } \\
\hline & II & ID & DD & & DD & DI & II & \\
\hline Age at diagnosis (years), $\mathrm{n}$ & & & & 0.976 & & & & 0.529 \\
\hline$\leq 65$ & 30 & 45 & 3 & & 25 & 40 & 13 & \\
\hline$>65$ & 9 & 15 & 1 & & 11 & 10 & 4 & \\
\hline Stage & & & & 0.152 & & & & 0.241 \\
\hline pT1 & 3 & 5 & 0 & & 4 & 3 & 1 & \\
\hline pT2a & 5 & 12 & 3 & & 7 & 6 & 7 & \\
\hline pT2b & 3 & 4 & 0 & & 2 & 4 & 1 & \\
\hline pT2c & 18 & 21 & 0 & & 16 & 18 & 5 & \\
\hline pT3a & 1 & 6 & 1 & & 2 & 4 & 2 & \\
\hline pT3b & 9 & 12 & 0 & & 5 & 15 & 1 & \\
\hline PSA level at diagnosis $(\mathrm{ng} / \mathrm{ml}), \mathrm{n}$ & & & & 0.647 & & & & 0.538 \\
\hline$\leq 4$ & 1 & 0 & 0 & & 1 & 0 & 0 & \\
\hline $4-10$ & 18 & 29 & 1 & & 19 & 21 & 8 & \\
\hline$>10$ & 20 & 31 & 3 & & 16 & 29 & 9 & \\
\hline Gleason score, $\mathrm{n}$ & & & & 0.475 & & & & 0.674 \\
\hline$\leq 7$ & 32 & 46 & 4 & & 30 & 38 & 14 & \\
\hline$>7$ & 7 & 14 & 0 & & 6 & 12 & 3 & \\
\hline Perineural invasion, $\mathrm{n}$ & & & & 0.886 & & & & 0.878 \\
\hline Positive & 22 & 36 & 2 & & 21 & 30 & 9 & \\
\hline Negative & 17 & 24 & 2 & & 15 & 20 & 8 & \\
\hline Surgical margin, $\mathrm{n}$ & & & & 0.925 & & & & 0.035 \\
\hline Positive & 16 & 24 & 2 & & 13 & 26 & 3 & \\
\hline Negative & 23 & 36 & 2 & & 23 & 24 & 14 & \\
\hline
\end{tabular}

MDM2, murine double minute-2; TP53, tumor protein 53; I, insertion; D, deletion; PSA, prostate specific antigen. pT1, pT2a, pT2b, pT2c, pT3a and pT3b are clinical stages of prostate cancer.

indicate that the 40-bp I/D polymorphism in the MDM2 gene promoter increases the risk of PCa in a sample of the Iranian population. Larger sample sizes with differing ethnicities are required to further investigate these findings.

\section{Acknowledgements}

The current study was supported by Zahedan University of Medical Sciences, Zahedan, Iran (grant no. 6728), a University of Manitoba Start-Up grant (grant no. 315992) and a Manitoba Medical Services Foundation grant (grant no. 8-2015-11). The authors would like to thank all individuals who willingly participated in the study. In addition, all authors acknowledge Dr Judi Smith (Research Facilitator, Health Sciences, University of Manitoba, Canada) for editing the original manuscript.

\section{References}

1. Siegel R, Ma J, Zou Z and Jemal A: Cancer statistics, 2014. CA Cancer J Clin 64: 9-29, 2014.

2. Farahmand M, Khademolhosseini F and Mehrabani D: Trend of prostate cancer in Fars Province, Southern Iran, 2001-2007. J Res Med Sci 15: 295-297, 2010.
3. Talaiezadeh A, Tabesh H, Sattari A and Ebrahimi S: Cancer incidence in southwest of iran: First report from khuzestan population-based cancer registry, 2002-2009. Asian Pac J Cancer Prev 14: 7517-7522, 2013.

4. Baade PD, Youlden DR, Cramb SM, Dunn J and Gardiner RA: Epidemiology of prostate cancer in the Asia-Pacific region. Prostate Int 1: 47-58, 2013.

5. SEER stat fact sheets: Prostate cancer. Surveillance e and end results program. http://seer.cancer.gov/statfacts/ html/prost.html. Accessed September 2, 2014

6. Carter BS, Beaty TH, Steinberg GD, Childs B and Walsh PC: Mendelian inheritance of familial prostate cancer. Proc Natl Acad Sci USA 89: 3367-3371, 1992.

7. Gronberg H, Damber L and Damber JE: Familial prostate cancer in Sweden. A nationwide register cohort study. Cancer 77: 138-143, 1996.

8. Johnson AM, Zuhlke KA, Plotts C, McDonnell SK, Middha S, Riska SM, Schaid DJ, Thibodeau SN, Douglas JA and Cooney KA: Mutational landscape of candidate genes in familial prostate cancer. Prostate 74: 1371-1378, 2014.

9. Chen LS, Fann JC, Chiu SY, Yen AM, Wahlfors T, Tammela TL, Chen $\mathrm{HH}$, Auvinen A and Schleutker J: Assessing interactions of two loci (rs4242382 and rs10486567) in familial prostate cancer: Statistical evaluation of epistasis. PLoS One 9: e89508, 2014.

10. Teerlink CC, Thibodeau SN, McDonnell SK, Schaid DJ, Rinckleb A, Maier C, Vogel W, Cancel-Tassin G, Egrot C, Cussenot $\mathrm{O}$, et al: Association analysis of 9,560 prostate cancer cases from the International Consortium of Prostate Cancer Genetics confirms the role of reported prostate cancer associated SNPs for familial disease. Hum Genet 133: 347-356, 2014. 
11. McBride OW, Merry D and Givol D: The gene for human p53 cellular tumor antigen is located on chromosome 17 short arm (17p13). Proc Natl Acad Sci USA 83: 130-134, 1986.

12. Tong WM, Hande MP, Lansdorp PM and Wang ZQ: DNA strand break-sensing molecule poly(ADP-Ribose) polymerase cooperates with p53 in telomere function, chromosome stability, and tumor suppression. Mol Cell Biol 21: 4046-4054, 2001.

13. Hong H, Takahashi K, Ichisaka T, Aoi T, Kanagawa O, Nakagawa M, Okita K and Yamanaka S: Suppression of induced pluripotent stem cell generation by the p53-p21 pathway. Nature 460: 1132-1135, 2009.

14. Marte B: Cancer: Super p53. Nature 420: 279, 2002.

15. Levine AJ and Oren M: The first 30 years of p53: Growing ever more complex. Nat Rev Cancer 9: 749-758, 2009.

16. Zhuo W, Zhang Y, Xiang Z, Cai L and Chen Z: Polymorphisms of TP53 codon 72 with breast carcinoma risk: Evidence from 12226 cases and 10782 controls. J Exp Clin Cancer Res 28: 115, 2009.

17. Momand J and Zambetti GP: Mdm-2: 'Big brother' of p53. J Cell Biochem 64: 343-352, 1997.

18. Bond GL, Hu W and Levine AJ: MDM2 is a central node in the p53 pathway: 12 years and counting. Current Cancer Drug Targets 5: 3-8, 2005.

19. Haupt Y, Maya R, Kazaz A and Oren M: Mdm2 promotes the rapid degradation of p53. Nature 387: 296-299, 1997.

20. Wu D, Zhang Z, Chu H, Xu M, Xue Y, Zhu H and Zhang Z: Intron 3 sixteen base pairs duplication polymorphism of $\mathrm{p} 53$ contributes to breast cancer susceptibility: Evidence from meta-analysis PloS One 8: e61662, 2013.

21. Bis of V, Salihović MP, Narancić NS, Skarić-Jurić T, Jakić-Razumović J, Janićijević B, Turek S and Rudan P: TP53 gene polymorphisms and breast cancer in Croatian women: A pilot study. Eur J Gynaecol Oncol 31: 539-544, 2010.

22. Mammano E, Belluco C, Bonafé M, Olivieri F, Mugianesi E, Barbi C, Mishto M, Cosci M, Franceschi C, Lise M and Nitti D: Association of p53 polymorphisms and colorectal cancer: Modulation of risk and progression. Eur J Surg Oncol 35: 415-419, 2009.

23. Xu B, Xu Z, Cheng G, Min ZC, Mi Y, Zhang ZZ, Tao J, Li PC, Wang ML, Tang JL, et al: Association between polymorphisms of TP53 and MDM2 and prostate cancer risk in southern Chinese. Cancer Genet Cytogenet 202: 76-81, 2010.

24. Mahasneh AA and Abdel-Hafiz SS: Polymorphism of p53 gene in Jordanian population and possible associations with breast cancer and lung adenocarcinoma. Saudi Med J 25: 1568-1573, 2004.

25. Dong D, Gao X, Zhu Z, Yu Q, Bian S and Gao Y: A 40-bp insertion/deletion polymorphism in the constitutive promoter of MDM2 confers risk for hepatocellular carcinoma in a Chinese population. Gene 497: 66-70, 2012.

26. Hu Z, Ma H, Lu D, Qian J, Zhou J, Chen Y, Xu L, Wang X, Wei Q and Shen H: Genetic variants in the MDM2 promoter and lung cancer risk in a Chinese population. Int J Cancer 118: 1275-1278, 2006.

27. Ma H, Hu Z, Zhai X, Wang S, Wang X, Qin J, Jin G, Liu J, Wang X, Wei Q and Shen H: Polymorphisms in the MDM2 promoter and risk of breast cancer: A case-control analysis in a Chinese population. Cancer Lett 240: 261-267, 2006.

28. Hashemi M, Omrani M, Eskandari-Nasab E, Hasani SS, Mashhadi MA and Taheri M: A 40-bp insertion/deletion polymorphism of Murine Double Minute2 (MDM2) increased the risk of breast cancer in Zahedan, Southeast Iran. Iran Biomed J 18: 245-249, 2014.

29. Hashemi M, Shahkar G, Simforoosh N, Basiri A, Ziaee SA, Narouie B and Taheri M: Association of polymorphisms in PRKCI gene and risk of prostate cancer in a sample of Iranian Population. Cell Mol Biol (Noisy-le-grand) 61: 16-21, 2015.

30. Hashemi M, Hanafi Bojd H, Eskandari Nasab E, Bahari A, Hashemzehi NA, Shafieipour S, Narouie B, Taheri M and Ghavami S Association of adiponectin rs1501299 and rs266729 gene polymorphisms with nonalcoholic fatty liver disease. Hepat Mon 13: e9527, 2013.

31. Wang-Gohrke S, Rebbeck TR, Besenfelder W, Kreienberg R and Runnebaum IB: p53 germline polymorphisms are associated with an increased risk for breast cancer in German women. Anticancer Res 18: 2095-2099, 1998.

32. Eskandari-Nasab E, Hashemi M, Amininia S, Ebrahimi M, Rezaei M and Hashemi SM: Effect of TP53 16-bp and beta-TrCP 9-bp INS/DEL polymorphisms in relation to risk of breast cancer. Gene 568: 181-185, 2015.
33. Pourmand G, Ziaee AA, Abedi AR, Mehrsai A, Alavi HA, Ahmadi A and Saadati HR: Role of PTEN gene in progression of prostate cancer. Urol J 4: 95-100, 2007.

34. Shaik AP, Jamil K and Das P: CYP1A1 polymorphisms and risk of prostate cancer: A meta-analysis. Urol J 6: 78-86, 2009.

35. Samzadeh M, Hasanzad M, Jamaldini SH, Haghdoost AA, Afshari M and Ziaee SA: Association of G/A polymorphism, rs266882, in AREI region of the prostate-specific antigen gene with prostate cancer risk and clinicopathological features. Urol J 9: 691-699, 2012.

36. Harris SL and Levine AJ: The p53 pathway: Positive and negative feedback loops. Oncogene 24: 2899-2908, 2005.

37. Bennett WP, Hussain SP, Vahakangas KH, Khan MA, Shields PG and Harris CC: Molecular epidemiology of human cancer risk: Gene-environment interactions and p53 mutation spectrum in human lung cancer. J Pathol 187: 8-18, 1999.

38. Kastan MB and Lim DS: The many substrates and functions of ATM. Nat Rev Mol Cell Biol 1: 179-186, 2000.

39. Tichy A, Vavrova J, Pejchal J and Rezácová M: Ataxia-telangiectasia mutated kinase (ATM) as a central regulator of radiation-induced DNA damage response. Acta Medica (Hradec Kralove) 53: 13-17, 2010.

40. Wade M, Li YC and Wahl GM: MDM2, MDMX and p53 in oncogenesis and cancer therapy. Nat Rev Cancer 13: 83-96, 2013.

41. Proestling K, Hebar A, Pruckner N, Marton E, Vinatzer U and Schreiber M: The Pro allele of the p53 codon 72 polymorphism is associated with decreased intratumoral expression of BAX and p21 and increased breast cancer risk. PLoS One 7: e47325, 2012.

42. Kubbutat MH, Jones SN and Vousden KH: Regulation of p53 stability by Mdm2. Nature 387: 299-303, 1997.

43. Bond GL, Hu W and Levine A: A single nucleotide polymorphism in the MDM2 gene: From a molecular and cellular explanation to clinical effect. Cancer Res 65: 5481-5484, 2005.

44. Meddeb M, Valent A, Danglot G, Nguyen VC, Duverger A, Fouquet $\mathrm{F}$, Terrier-Lacombe MJ, Oberlin $\mathrm{O}$ and Bernheim A: MDM2 amplification in a primary alveolar rhabdomyosarcoma displaying a t(2;13)(q35;q14). Cytogenet Cell Genet 73: 325-330, 1996.

45. Bueso-Ramos CE, Yang Y, deLeon E, McCown P, Stass SA and Albitar M: The human MDM-2 oncogene is overexpressed in leukemias. Blood 82: 2617-2623, 1993.

46. Watanabe T, Hotta T, Ichikawa A, Kinoshita T, Nagai H, Uchida T, Murate T and Saito H: The MDM2 oncogene overexpression in chronic lymphocytic leukemia and low-grade lymphoma of B-cell origin. Blood 84: 3158-3165, 1994.

47. Mittal RD, George GP, Mishra J, Mittal T and Kapoor R: Role of functional polymorphisms of P53 and P73 genes with the risk of prostate cancer in a case-control study from Northern India. Arch Med Res 42: 122-127, 2011.

48. Faghani M, Ghasemi FM, Nikhbakht M and Salehi M: TP53 PIN3 polymorphism associated with breast cancer risk in Iranian women. Indian J Cancer 48: 298-302, 2011.

49. Lajin B, Alhaj Sakur A and Alachkar A: Association between polymorphisms in apoptotic genes and susceptibility for developing breast cancer in Syrian women. Breast Cancer Res Treat 138: 611-619, 2013.

50. Hu Z, Li X, Yuan R, Ring BZ and Su L: Three common TP53 polymorphisms in susceptibility to breast cancer, evidence from meta-analysis. Breast Cancer Res Treat 120: 705-714, 2010.

51. Wu X, Zhao H, Amos CI, Shete S, Makan N, Hong WK, Kadlubar FF and Spitz MR: p53 genotypes and haplotypes associated with lung cancer susceptibility and ethnicity. J Natl Cancer Inst 94: 681-690, 2002.

52. Malik MA, Sharma K, Goel S, Zargar SA and Mittal B: Association of TP53 intron 3,16 bp duplication polymorphism with esophageal and gastric cancer susceptibility in Kashmir Valley. Oncol Res 19: 165-169, 2011.

53. Pouladi N, Kouhsari SM, Feizi MH, Dehghan R, Azarfam P and Farajzadeh D: Lack of association of intron 316 bp polymorphism of TP53 with breast cancer among Iranian-Azeri patients. Asian Pac J Cancer Prev 15: 2631-2634, 2014.

54. Naccarati A, Pardini B, Polakova V, Smerhovsky Z, Vodickova L, Soucek P, Vrana D, Holcatova I, Ryska M and Vodicka P: Genotype and haplotype analysis of TP53 gene and the risk of pancreatic cancer: An association study in the Czech Republic. Carcinogenesis 31: 666-670, 2010.

55. Costa S, Pinto D, Pereira D, Rodrigues H, Cameselle-Teijeiro J, Medeiros R and Schmitt F: Importance of TP53 codon 72 and intron 3 duplication 16bp polymorphisms in prediction of susceptibility on breast cancer. BMC Cancer 8: 32, 2008. 
56. Pietsch EC, Humbey $\mathrm{O}$ and Murphy ME: Polymorphisms in the p53 pathway. Oncogene 25: 1602-1611, 2006.

57. Gemignani F, Moreno V, Landi S, Moullan N, Chabrier A Gutiérrez-Enríquez S, Hall J, Guino E, Peinado MA, Capella G and Canzian F: A TP53 polymorphism is associated with increased risk of colorectal cancer and with reduced levels of TP53 mRNA. Oncogene 23: 1954-1956, 2004.

58. Xu B, Mi YY, Min ZC, Cheng G, Tong N, Tao J, Li PC, Wang ML, Tang JL, Zhang ZD, et al: p53 codon 72 increased biochemical recurrence risk after radical prostatectomy in a southern Chinese population. Urol Int 85: 401-405, 2010.
59. Lin VC, Huang CY, Lee YC, Yu CC, Chang TY, Lu TL, Huang SP and Bao BY: Genetic variations in TP53 binding sites are predictors of clinical outcomes in prostate cancer patients. Arch Toxicol 88: 901-911, 2014. 